\title{
Evaluating Forage Quality of Pastures
}

\section{S. CAMPBELL AND A. D. DOTZENKO}

Highlight: Ten irrigated pastures located in northeastern Colorado were evaluated for forage quality during the 1972 growing season. Most of the pastures used the center-pivot type of sprinkler system and consisted mainly of mixtures of alfalfa (Medicago sativa L.), orchardgrass (Dactylis glomerata L.), and smooth bromegrass (Bromus inermis Leyss.) in varying proportions. Thirteen factors for quality were evaluated from each pasture from samples obtained over a 5-month period $\mathrm{Mg}, P, K$, crude protein, in vitro digestibility, cell wall constituents, cell contents, hemicellulose, cellulose, lignin, and silica showed significant fluctuations during the growing season, while calcium and ash insoluble in neutral detergent remained fairly constant.

Changes that occurred during the growing season could be accounted for by time of harvest, management practices, species, and other environmental factors such as differences in climate and soil. In spite of differences between pastures, satisfactory regression functions were developed to give good estimations of forage quality using in vitro dry matter digestibility as the dependent variable. By submitting the data to the stepwise regression calculation techniques, good predictive equations for IVDMD were developed that can readily be applied to pastures in northeastern Colorado regardless of location, management, or species composition.

Pasture management and use underwent a minor revolution in eastern Colorado in the mid-1960's with the advent of the center-pivot sprinkler system. Under most conditions, pastures can furnish a more economical feed for grazing animals than can any harvested crop. In spite of this, not all irrigated pastures in this region can produce forage that will furnish all of the dietary needs of animals as evidenced by animal responses. Supplementary feed must often be supplied, and the amount fed will depend in part on the quality of the forage consumed. Therefore, it is evident that the quality of forage produced is of great economic importance.

Indirect methods of predicting in vivo digestibility of forages have received much attention due to the high cost and difficulty of conducting conventional in vivo trials. The Tilley and Terry (1963) two-stage technique for the in vitro digestion of forages and the forage fiber analyses as developed by Goering and Van Soest (1970) give good estimations of forage

The authors are former graduate research assistant and professor of agronomy, Colorado State University, Fort Collins, respectively.

The research is a contribution from the Department of Agronomy, Colorado State University Ex periment Station, Fort Collins. Portions of a thesis submitted by the senior author as partial requirement for the MS degree. Published with the approval of the Director of the Colorado State University Experiment Station as Scientific Series Paper No. 1990.

Manuscript received July 19, 1974. quality and lend themselves quite readily to analyzing large numbers of samples.

The objectives of this study were threefold: (1) determine the variations in forage quality of irrigated pastures during the growing season; (2) determine the relationships between certain forage constituents and in vitro dry matter digestibility; and (3) develop regression equations that give good estimates of forage quality.

\section{Materials and Methods}

Ten pastures, all located in northeastern Colorado, were selected for study and represented a cross section in environmental conditions and systems of management. Eight pastures used the center-pivot sprinkler; the other two used a solid set and a border-flood system of irrigation. Fertilizer applications varied, and certain pastures were rotationally grazed while others were grazed continuously. Pasture species consisted of alfalfa, orchardgrass, and smooth bromegrass in varying proportions. Soils ranged from sandy soils (sandhills) to loams.

Pastures were harvested by hand, using shears or sickle at approximately 30-day intervals and were selected from sites that were currently being grazed, as well as those that were beginning to be grazed. Oven-dry samples $\left(65-70^{\circ} \mathrm{C}\right)$ were analyzed in duplicate for $\mathrm{N}, \mathrm{Ca}, \mathrm{P}, \mathrm{K}, \mathrm{Mg}$, in vitro dry matter digestibility (IVDMD), cell wall constituents (CWC), cell contents, ash insoluble in neutral detergent, hemicellulose, cellulose, lignin, and silica. Nitrogen percentages were determined by the micro-kjeldahl technique. Following a wet digestion, using nitric, sulphuric, and perchloric acids, $\mathrm{P}$ was determined using the method outlined by Barton (1948). Ca, $\mathrm{Mg}$, and $\mathrm{K}$ were determined with a Perkin-Elmer atomic absorption spectrophotometer as outlined by David (1959) and Allan (1958).

IVDMD's were determined according to the Tilley-Terry procedure (1963) with direct acidification with the addition of pepsin as explained by Alexander and McGowen (1961). Neutral detergent analysis, acid detergent anaiysis, and silica were determined according to methods outlined by Goering and Van Soest (1970) and Van Soest and Wine (1968).

The results were analyzed by use of a two-way analysis of variance, and Tukey's HSD test was used as a measure for significant differences. Stepwise regression analyses were calculated, in which time of harvest (May $=1$; June $=$ $2 ; \ldots$ Sept. $=5$ ) was deleted, forced, or used as a freed independent variable.

\section{Results and Discussion}

Monthly concentrations of 13 constituents determined from pasture forages are reported in Table 1 . With the 
Table 1. Mean percentages of chemical constituents in oven-dry forages from irrigated pastures harvested at different time intervals during 1972.

\begin{tabular}{lrrrrrr}
\hline \hline $\begin{array}{l}\text { Chemical } \\
\text { constituent }\end{array}$ & May & June & July & August & September & HSD \\
\hline Calcium & 0.57 & 0.54 & 0.58 & 0.65 & 0.72 & NS \\
Magnesium & 0.21 & 0.25 & 0.27 & 0.29 & 0.30 & 0.05 \\
Phosphorus & 0.43 & 0.34 & 0.39 & 0.38 & 0.41 & 0.06 \\
Potassium & 3.98 & 3.32 & 3.49 & 3.68 & 3.96 & 0.48 \\
Crude protein & 26.70 & 20.10 & 19.80 & 19.00 & 24.10 & 4.80 \\
IVDMD & 73.80 & 63.80 & 63.70 & 61.80 & 64.10 & 4.80 \\
Cell contents & 55.70 & 45.90 & 48.40 & 48.50 & 53.40 & 5.70 \\
Cell wall & & & & & & \\
$\quad$ constituents & 44.30 & 54.10 & 51.60 & 51.50 & 46.60 & 5.70 \\
Ash insoluble & & & & & & \\
in neutral & & & & & & \\
detergent & 2.20 & 2.40 & 2.70 & 3.00 & 3.10 & NS \\
Hemicellulose & 17.20 & 19.20 & 16.70 & 16.20 & 15.10 & 2.50 \\
Cellulose & 20.90 & 26.20 & 25.30 & 25.30 & 22.50 & 3.00 \\
Lignin & 2.90 & 4.50 & 4.70 & 4.90 & 4.00 & 1.10 \\
Silica & 3.10 & 4.10 & 4.60 & 4.90 & 4.80 & 1.30 \\
\hline
\end{tabular}

Tukey's HSD values (5\% level).

exception of calcium and ash insoluble in neutral detergent, all constituents showed significant variations throughout the sampling period. $\mathrm{P}, \mathrm{K}$, crude-protein, IVDMD, and cell contents had higher percentages during May, with lower values in June, July, and August and with a trend toward higher percentages during the month of September. There seems to be a relationship between the constituents showing decreased values and the relatively hot temperatures that occur during June, July, and August. These differences are quite striking for crude protein, cell contents, and cellulose. There also is a marked depression in IVDMD levels from the month of May in comparison to levels obtained during the other 4 months.

In the case of CWC, cellulose, lignin, and silica, the trend was to show increased concentrations during the warm part of the growing season (June, July, and August). It appears that the perennial forages reacted by an increase in structural components with the advent of high temperatures. The increase in structural components is generally coupled with a decrease in digestibility as is borne out by the negative correlation coefficients between the various constituents in Table 2. The adverse effect of cell wall constituents (cellulose, hemicellulose, lignin, and silica) on a nutritive evaluation such as IVDMD is readily seen. In addition, a close positive relationship exists between the cell wall constituents and the components making up this fraction. Since cellulose is the most abundant fraction, one would expect a higher degree of association, and this is indicated by a high $r$-value of 0.90 .

Table 2. Correlation coefficients between various constituents from forage harvested at different times from 10 irrigated pastures during 1972.

\begin{tabular}{lc}
\hline Variables & $r$ value $^{1}$ \\
\hline IVDMD X cell wall constituents & -0.82 \\
IVDMD X ash insoluble in neutral detergent & -0.40 \\
IVDMD $\times$ hemicellulose & -0.31 \\
IVDMD X cellulose & -0.77 \\
IVDMD X lignin & -0.74 \\
IVDMD $\times$ silica & -0.57 \\
IVDMD X crude protein & 0.66 \\
Cell wall constituents $\times$ hemicellulose & 0.72 \\
Cell wall constituents $\times$ cellulose & 0.90 \\
Cell wall constituents $\times$ lignin & 0.67 \\
Cell wall constituents $\times$ silica & 0.37 \\
Cell wall constituents $\times$ crude protein & -0.72 \\
\hline
\end{tabular}

${ }^{1}$ All factors are significant at the .01 level.
Table 3. Summary table of stepwise regression with time of harvest deleted as an independent variable and IVDMD as the dependent variable.

\begin{tabular}{clcccc}
\hline \hline $\begin{array}{c}\text { Step } \\
\text { no. }\end{array}$ & Variable entered & $r$ & $R$-square & $R$-square & $\begin{array}{c}\text { Increase in } \\
\text { value }^{1}\end{array}$ \\
\hline 1 & Cell-wall constituents & .82 & .67 & .67 & 99.26 \\
2 & Hemicellulose & .91 & .84 & .17 & 51.80 \\
3 & Silica & .93 & .87 & .03 & 12.95 \\
\hline
\end{tabular}

${ }^{1}$ An $F$ value of 4.02 or greater is needed for a variable to enter this program.

Hemicellulose and lignin, the other two major components of cell wall constituents, also had relatively high degrees of association as $r$-values of 0.72 and 0.67 were obtained, respectively. Van Soest and Wine (1967) have shown that the digestibility of hemicellulose and cellulose by ruminants is negatively associated with the amount of lignin and silica present in the cell wall constituent fraction. Significant negative correlations were found in this study between IVDMD, lignin, and silica (Table 2) and tend to support Van Soest and Wine's conclusions.

With the hope of finding which group of constituents and in what combination gave the best approximation of IVDMD, various regression equations were determined using IVDMD as the dependent variable. Table 3 gives the results obtained where a three-variable function was calculated with time of harvest deleted as an independent variable. The first variable to enter the equation was the cell wall constituent fraction as this had the highest degree of correlation $(-0.82)$ with IVDMD, followed by hemicellulose and silica. All other factors had F values that were too low for their inclusion in the equation. The addition of silica in the equation did little to improve $R$-square value. The equation with time of harvest deleted as an independent variable is as follows:

IVDMD $=104.64-1.13 \mathrm{CWC}+1.23 \mathrm{HC}-0.835$

where $\mathbf{C W C}=$ cell wall constituents with a standard error of the coefficients of $0.08 ; \mathbf{H C}=$ hemicellulose with a standard error of the coefficient of $0.18 ; \mathbf{S}=$ silica with a standard error of the coefficients of 0.23 ; and IVDMD = in vitro dry-matter digestibility with a standard error of estimate of 2.21 .

Table 4 presents the results obtained when the time of harvest is entered as a variable with IVDMD still being held as a dependent variable. By entering time of harvest into the equation, this permitted phosphorus to also enter, thereby creating a five-variable equation. a total $R$-square value of 0.93 was obtained, but most of the increase could be accounted for by the cell wall constituents and time of harvest with hemicellulose, silica, and phosphorus adding slightly to the accuracy of the equation. The regression equation with time of harvest freed as an independent variable is expressed as follows:

Table 4. Summary table of stepwise regression with time of harvest freed as an independent variable and IVDMD as the dependent variable.

\begin{tabular}{clcccc}
\hline \hline $\begin{array}{c}\text { Step } \\
\text { no. }\end{array}$ & Variable entered & $r$ & $R$-square & $R$-square & value $^{1}$ \\
\hline 1 & Cell-wall constituents & .82 & .67 & .67 & 99.26 \\
2 & Time of harvest & .94 & .88 & .21 & 84.68 \\
3 & Hemicellulose & .95 & .91 & .03 & 13.84 \\
4 & Silica & .96 & .92 & .01 & 6.85 \\
5 & Phosphorus & .96 & .93 & .01 & 5.72 \\
\hline 1 An $F$ & value of 3.99 or greater is needed for a variable to enter this
\end{tabular}
program. 
IVDMD $=102.16-1.27$ Time $+8.91 \mathrm{P}-0.88 \mathrm{CWC}+0.59 \mathrm{HC}-0.60 \mathrm{~S}$ where Time $=$ months with a standard error of the coefficients of $0.23 ; \mathbf{P}=$ phosphorus with a standard error of the coefficients of $3.72 ; \mathbf{C W C}=$ cell wall constituents with a standard error of the coefficients of $0.08 ; \mathbf{H C}=$ hemicellulose with a standard error of the coefficients of $0.17 ; \mathbf{S}=$ silica with a standard error of the coefficients of 0.19 ; and IVDMD $=$ in vitro dry-matter digestibility with a standard error of estimate of 1.70 .

The standard error of the estimate of IVDMD is considerably lower (1.70) than in the standard error (2.21) in the previous equations where only three variables were included. Since it appears that only minimal accuracy is sacrificed by the elimination of phosphorus and silica, the following three-variable equation gives the best criteria for estimating IVDMD, considering time and economy.

The regression equation with time of harvest freed as an independent variable but excluding phosphorus and silica is expressed as follows:

IVDMD $=109.10-1.41$ Time $-1.03 \mathrm{CWC}+0.71 \mathrm{HC}$

where Time $=$ months with a standard error of the coefficients of 0.24 ; CWC $=$ cell wall constituents with a standard error of the coefficients of $0.07 ; \mathbf{H C}=$ hemicellulose with a standard error of the coefficients of 0.19; and IVDMD = in vitro dry matter digestibility with standard error of estimate of 1.90 .

One may ask, since hemiccllulose does not contribute much to the $R$-square value, why it is included in the equation. If it is excluded, the standard error of the estimate for IVDMD increases to 2.15 . It appears that the equation with time of harvest deleted would be much less accurate than any of the equations containing this variable. This is probably due to the changes in growth patterns and composition of the species within a given pasture.

Goering and Van Soest (1970) produced a summative equation that includes cell contents, the estimated digestion coefficient of cell walls, and metabolic fecal losses. Their equation, even though it may predict digestibilities as accurate as the one developed by this study, requires considerable more time, effort, and expense, as the equation accounts for metabolic fecal losses.

\section{Conclusions}

Using IVDMD as the dependent variable in developing regression equations designed to find an equation that could be used as a substitute for this time-consuming laboratory analysis, it was concluded that optimum prediction of IVDMD could be obtained where time of harvest, cell wall constituents, and hemicellulose were included as variables. The addition of silica and phosphorus did little to increase the accuracy of the equation.

\section{Literature Cited}

Alexander, R. H., and M. McGowan. 1961. A filtration procedure for the in vitro determination of digestibility of herbage. J. Brit. Grassl. Soc. 16:275-276.

Allan, J. E. 1958. Atomic-absorption spectrophotometry with special reference to the determination of magnesium. Analyst. 83:466-471.

Barton, C. J. 1948. Photometric analysis of phosphate rock. Anal. Chem. 20:1068-1073.

David, D. J. 1959. Determination of calcium in plant material by atomic-absorption spectrophotometry. Analyst. 84:536-545.

Goering, H. K., and P. J. Van Soest. 1970. Forage fiber analyses. Agr. Res. Serv. U.S. Dep. Agr., Agr. Handbook No. 379.

Tilley, J. M., and R. A. Terry. 1963. A two-stage technique for the in vitro digestion of forage crops. J. Brit. Grassl. Soc. 18:104-111.

Van Soest, P. J., and R. H. Winc. 1968. Determination of lignin and cellulose in acid-detergent fiber with permanganate. J. Ass. Offic. Anal. Chem. 51:780-785.

Van Soest, P. J., and R. H. Wine. 1967. Use of detergent in the analysis of fibrous feeds. IV. Determination of plant cell-wall constituents. J. Ass. Offic. Anal. Chem. 50:50-55.

\section{New Now!}

\section{A GLOSSARY OF TERMS USED IN RANGE MANAGEMENT}

$\star$ Compiled and edited by the

Range Term Glossary Committee

of the Society for Range Management

M. M. Kothmann, Chairman

$\star$ This second edition offers more than 550 terms used in range science. It is designed to assign and develop precise meanings in the science and thus be of service to scientists, technicians, teachers, students, ranchers, and laymen.

44 pages

softbound

$\$ 1.25$ postpaid

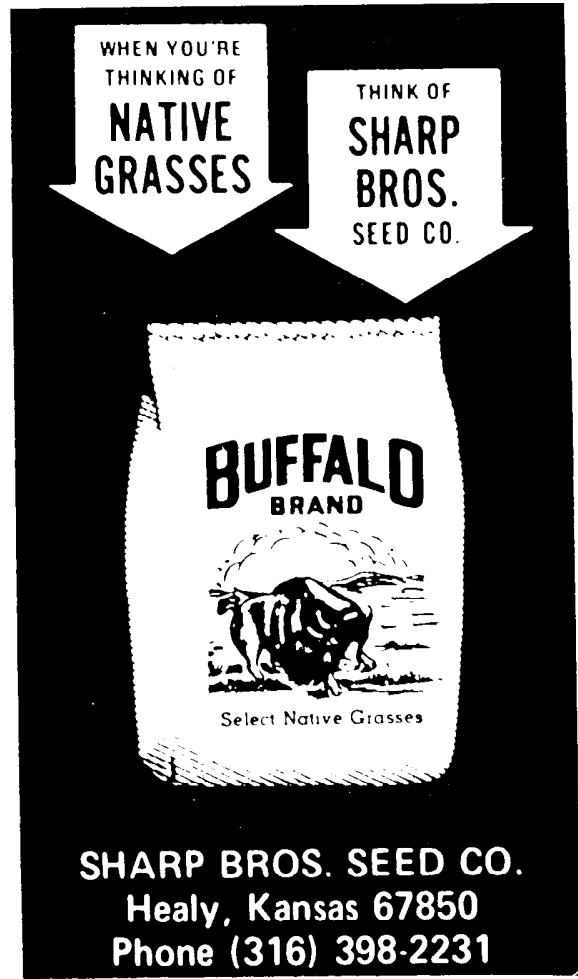

